\title{
CONSUMER SUSTAINABILITY AND RESPONSIBILITY: BEYOND GREEN AND ETHICAL CONSUMPTION
}

\section{ODRŽIVOST I ODGOVORNOST POTROŠAČA: POSLIJE ZELENE I ETIČKE POTROŠNJE}

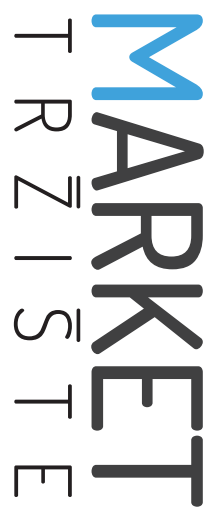

\author{
Market-Tržište \\ Vol. 28, No. 2, 2016, pp. 143-157 \\ UDK 658.89:502/504 \\ 65.01:316.663 \\ Preliminary communication
}

\begin{abstract}
Maja Hosta ${ }^{a}$, Vesna Žabkarb
a) Faculty of Economics, University of Ljubljana, Kardeljeva pl. 17, 1000 Ljubljana, SLOVENIA, maja.hosta@ef.uni-lj.si

b) Faculty of Economics, University of Ljubljana, Kardeljeva pl. 17, 1000 Ljubljana, SLOVENIA, vesna.zabkar@ef.uni-lj.si
\end{abstract}

\begin{abstract}
Purpose - Most literature regarding sustainable behavior is based on the assumption that the reduction of consumption is inherently positive (mainly in the form of positive environmental consequences) and based on ethical considerations. However, the issue of the social consequences of this reduction and self-interested intentions in consumption is not generally open to debate. This paper aims to identify dimensions of sustainable and responsible consumer behavior, distinguish between the two concepts, and present consumer obstacles to acting responsibly in all aspects that a sustainability agenda would suggest.
\end{abstract}

Design/Methodology/Approach - The paper includes a literature review, proposes a framework of responsible and sustainable consumption (RSCB), and offers a set of propositions to achieve responsible and sustainable consumption. Insights from personal interviews with consumers are added for the sake of additional understanding of the concepts presented.

Findings and implications - Through the RSCB framework, we show the potential trade-off decisions consumers have to make in order to implement sustainability and responsibility issues in everyday consumer decision processes. Struggles between doing what is good for them and what is good for the environment and society could be a reason why consumers have

\section{Sažetak}

Svrha - Većina se literature o održivom ponašanju zasniva na pretpostavci da je smanjenje potrošnje samo po sebi pozitivno (uglavnom zbog pozitivnih posljedica na okoliš) i temeljeno na etičkim razmatranjima. Međutim, pitanje o društvenim posljedicama tog smanjenja i namjerama iz vlastitog interesa, općenito nije otvoreno za raspravu. Cilj rada jest identificirati dimenzije održivog i odgovornog ponašanja potrošača, razlikovati ta dva koncepta i predstaviti prepreke za odgovorno djelovanje potrošača u svim aspektima koji bi se mogli odnositi na održivost.

Metodološki pristup - Rad uključuje pregled literature, predlaže okvir održive i odgovorne potrošnje te nudi niz prijedloga za postizanje odgovorne i održive potrošnje. Dodani su uvidi iz osobnih intervjua s potrošačima radi boljeg razumijevanja prikazanih koncepata.

Rezultati i implikacije - Kroz predloženi okvir pokazujemo potencijalne kompromisne odluke potrošača koje oni trebaju donijeti kako bi implementirali održiva i odgovorna pitanja u svakodnevnom procesu odlučivanja. Borbe između onoga što je dobro za njih i što je dobro za okoliš i društvo, mogle bi biti razlogom zašto potrošači imaju problema u postizanju odgovorne i održive potrošnje.

Ograničenja - Kvalitativno istraživanje temeljeno na malom uzorku osobnih intervjua ne dozvoljava poopćavanje. 
difficulties achieving responsible and sustainable consumption.

Limitations - Qualitative study based on a small sample of personal interviews does not allow for generalizations.

Originality - A research gap in understanding the dimensions of sustainable and responsible consumer actions in terms of their emphasis (environmental and social) and intentions (self-interest and other-interest) is addressed. By understanding those two dimensions of behavior, managers and consumers can resolve consumer sustainability and responsibility dilemmas that arise from a one-dimensional view in order to move sustainability research and practice forward.

Keywords - environmentally sustainable consumer behavior, socially sustainable consumer behavior, consumer responsibility, trade-offs
Doprinos - Adresiran je istraživački jaz u razumijevanju dimenzija održivog i odgovornog djelovanja potrošača u pogledu naglašavanja (okoliša i društva) te namjera (vlastitog interesa i interesa drugih). Razumijevanjem tih dviju dimenzija ponašanja, menadžeri i potrošači mogu riješiti potrošačeve dileme o održivosti i odgovornosti koje proizlaze iz jednodimenzionalnog pogleda te unaprijediti istraživanja i praksu održivosti.

Ključne riječi - održivo ponašanje potrošača prema okolišu, održivo ponašanje potrošača prema društvu, potrošačeva odgovornost, kompromisi 


\section{INTRODUCTION}

Consumers with their everyday consumption decisions can help achieve or hinder goals for a more sustainable future. Consumer behavior that leads to a better outlook is often described with words such as sustainable, ethical, responsible, environmentally friendly, or socially friendly (Belz \& Peattie, 2012; Harrison, Newholm \& Shaw, 2005; Webb, Mohr \& Harris, 2008). The question is whether consumers need to - and should - take responsibility through their purchases (Moisander, 2007; Valor, 2008) or whether they perceive consumption as an activity that should not be constrained by environmental and social issues; but should rather merely fulfill their needs and rights (Schrader, 2007). Are consumers responsible primarily for their own wellbeing, or for the wellbeing of others, when they buy products (Barnett, Cafaro \& Newholm, 2005)? And, if they do take on the responsibility to make the world more sustainable, should they expect positive consequences in both the natural and social environment? Are there any differences between consumers who act out of concern for nature and those who act out of concern for society?

Although these questions have attracted theoretical and practical attention in recent years (e.g. Grebitus et al., 2012; Hult, 2011; McEachern \& Carrigan, 2012; Schrader \& Thøgersen, 2011), our literature review shows a lack of clear understanding of consumers' intent for responsibility and their emphasis on environmental and social issues. In the current body of literature, there is a general understanding that sustainability and sustainable behavior consist of several dimensions (e.g. environmental, social, and economic) and that different consumers put different emphases on environmental, social, or economic issues (Belz \& Peattie, 2012). The inclusion of all three dimensions in consumer research designs is rare, although some may be found (e.g. Roberts, 1995). Environmental and social issues are usually researched separately; for instance, more emphasis is given to one, e.g. natural environ- ment (Bridges \& Wilhelm, 2008), or else different issues are put under one dimension, such as ethical concerns (Creyer, 1997). Choi \& Ng (2011) observed that "lack of attention to sustainability, as a concept with multiple dimensions, has presented a developmental gap in green marketing literature, sustainability, and marketing literature for decades" (p. 269). From the theoretical perspective, this is seen in unclear definitions of concepts and under-researched topics like consumer trade-offs. From the managerial and marketing practice perspective, issues such as segmentation of consumers and development of complex sustainability strategies are not well researched or implemented in practice. Marketers need to better understand their consumers in order to align their sustainable strategic objectives with consumer needs and behavior and more efficiently target potential responsible consumers.

The first aim of the paper is, thus, to make a clear distinction between the sustainability and responsibility of consumer behavior and explore their different theoretical dimensions. The second aim of this paper is to explore a variety of responsible consumption practices and fundamental differences that arise from purchase, usage, disposal, or other environmentally or socially friendly behavior. To achieve these aims, we undertook a literature review and in-depth interviews with consumers to explore different consumer sustainability practices.

The paper explores different dimensions/levels of consumer sustainability and responsibility based on the works of Chabowsk, Mena and Gonzalez-Padron (2011) and Carroll (1991) to explain social responsibility, as well as on sustainability literature to create a framework for responsible sustainable consumer behaviors (RSCB) and present propositions for further research. In this framework, consumer behaviors can differ in terms of motivations for acting responsibly (intent) and their impact on specific dimensions of sustainability (emphasis). It helps to better explain the complex and sometimes paradoxical behavior of responsible consum- 
ers, which has been acknowledged recently by several authors (Jägel, Keeling, Reppel \& Gruber, 2012; Moisander, 2007). Researchers, for example, found that people have to constantly balance between the needs of their families, the needs of society and the needs of nature (Jägel et al., 2012) and encounter paradoxes, such as when behavior that is intended to protect the natural environment has a negative impact on personal health (e.g. the toxins found in reusable bags) (Klick \& Wright, 2012). We also want to point out that responsible consumer behavior is not necessarily ethically motivated. Consumer responsibility can be based on economic, legal, ethical, or philanthropic motives, and their behavior can have a positive influence on environmental or social sustainability.

Our main contributions to previous body of work in the field is the following: first, we clearly acknowledge different dimensions of consumer sustainability and responsibility simultaneously and thus broaden the research perspective in marketing to go "beyond green" and ethical studies; second, we present the framework from a consumer perspective and empirically explore different consumer sustainability and responsibility practices.

We have organized the rest of this paper as follows. First, we present the methodology used in the paper. Then, we look at the literature of sustainability and responsibility concepts and combine the findings with in-depth consumer interviews to add understanding of the under-researched dimensions of sustainability (social dimension) and responsibility (self-interest) and develop specific research propositions. We then integrate the concepts of sustainability and responsibility in order to develop the conceptual framework. We end the paper with conclusions and future directions.

\section{METHOD}

Current research is based on literature review and qualitative research to add to the understanding of the consumer perspective of sus- tainability and responsibility. We first looked at the literature in the field of sustainable marketing, consumer responsibility, and corporate responsibility. On account of a lack of information regarding the social sustainability dimension and self-interested behaviors of responsibility dimension, we conducted a further qualitative research to expand the understanding of those two under-researched dimensions. We chose personal interviews as our method of inquiry; it is generally perceived as the most frequently accepted and recommended source of information in ethical research, since ethically related research is usually influenced by a high degree of social desirability (Carrigan \& Attalla, 2001; Carrington, Neville $\&$ Whitwell, 2010). Also, the results of qualitative research can later be used as a source of information for additional quantitative research. Personal interviews were chosen, because the aim of the research was to gain in-depth understanding of the whole process of responsible consumption of a particular consumer in a way that he or she represents individual and not group views. Ten individuals aged between 25 and 65 (6 females, 4 males, with high-school education or higher, middle- or upper-income households, employed or retired, two without children) were interviewed. Our focus was to gather opinions of a typical consumer with some - though not an extreme - degree of environmental or social concern. Respondents were selected randomly. Data were selected in a Central European country with a developed economy. Open-ended questions were used in order to understand and gather their opinions about their responsibilities toward themselves as consumers, the natural and social environment, their motives to act and the whole process of responsible behavior from concern to action. Respondents were prompted to talk about the most pressing problems of today's natural and social environment, about differences between the issues of environmental, social and economic sustainability, and their manifestation in everyday consumption. The context of small-value purchases/FMCG was more exposed in interviews than higher-value products. Interviews lasted up to an hour and all interviewees 
gave their informed consent prior to the inclusion in the study and recording of the interview. Data were collected according to McCracken's (1988) recommendations for long interviews and analyzed following the procedures recommended by Miles and Huberman (1994), consisting of data reduction, data display, and conclusion drawing. The data reduction process began by transcription of audio-taped interviews, organization of notes and observations. Data were reduced and organized by using coding to create categories of information and detect patterns in answers, which enabled us to compare the respondents' attitudes and opinions. Content analysis was used to gain an in-depth understanding of each interviewee's perspective. Data were displayed in tables to gain a clearer understanding of consumption patterns. Cross-personal comparisons, examination of patterns and themes provided the basis for drawing conclusions.

\section{CONSUMER SUSTAINABILITY AND RESPONSIBILITY}

Responsibility is defined as an intention to act based on the acknowledgement of one's duties toward self or others (Schrader, 2007). Typically, researchers view consumer responsibility as being motivated by ethical or philanthropic concerns. Albeit similar to Carroll's (1991) pyramid of corporate responsibility, which lists economic, legal, ethical, and philanthropic levels, it can also be a consequence of self-interest or legal obligations (Belz \& Peattie, 2012). Sustainability, on the other hand, is the awareness of the longterm environmental and social impact of one's actions (Epstein, 2008).

\section{1. "More than green" - sustainability as a multidimensional construct in marketing}

Sustainability is comprised of three dimensions; namely, environmental (planet), social (people), and economic (profits) (Cato, 2009; Epstein,
2008). Those three issues could either be seen as equally important or the latter two as bound by environmental constraints (Cato, 2009). Environmental sustainability presents natural environmental constraints, such as energy and water supplies, or clean air availability. Social sustainability is coupled with protecting human rights, providing equal opportunities for everyone and ensuring economic sustainability with continuous profit creation and money availability, to name just a few examples. The economic dimension is sometimes excluded from the definition of sustainability and, instead, is considered as the final output or effect (Chabowski et al., 2011). Moreover, some authors are merging the social and economic dimensions of sustainability (Singh, de los Salmones Sanchez \& del Bosque, 2008), and the conclusion regarding which dimensions are the most important is not quite certain (Chabowski et al., 2011, p. 66). These issues are increasingly being included in the measurement of companies' success with performance evaluations like "triple bottom line" (Hubbard, 2009) and are also affecting the everyday decisions of consumers. They require companies and consumers to look beyond their self-interest and take a broader view of their business and behavior.

Companies and consumers are striving to become better citizens; although, as Epstein (2008) has observed, companies have problems with equally managing the environmental, social, and economic/financial aspects of sustainability. As observed by several authors (Chabowski et al., 2011; Choi \& Ng, 2011; Roberts, 1995; Webb et al., 2008), marketing has continually emphasized the environmental dimension of sustainability. For instance, Chabowski et al. (2011) looked at sustainability research in a bibliometric study of sustainability issues in marketing that spanned over 50 years. One of the important topics that stemmed from the analysis was the distinction between the social and environmental dimensions of sustainability and was seen as "imperative for the enrichment of the sustainability literature" (p. 64). Chabowski 
and others (2011) also justify the same through observations from the corporate world, where some companies already distinguish between environmental and social performance, based on different measures they utilize to assess each metric and to determine the results of sustainability initiatives. Choi \& Ng (2011) argue that current literature "does not offer an examination of the notion that different dimensions of sustainability can exist in the minds of consumers" (p. 270). Contemporary researchers also support this distinction and examine consumer responses regarding environmental and economic dimensions of sustainability. Researchers in other disciplines found similar discrepancies. Seuring and Müller (2008) analyzed sustainable supply chain management literature and found that the majority of articles address environmental issues (around 70\%), fewer address social issues (10\%), while others integrate both dimensions. Interestingly, the aforementioned integration was only found in research published after 2002.

Herein, some possible explanations are provided for the current situation. Increasing consumer concerns for the environment (first in the 1970s, then in the 1990s and again in recent years) provides many opportunities for marketers to engage consumers in environmentally friendly consumption. Lots of green color in advertisements; brown, natural-looking packaging; natural ingredients; and buzzwords like green, eco and bio have been embedded in products and communications. "Green" has become part of the acquisition, purchase, usage, and post-usage stage, thus presenting various opportunities for consumers to express their concern for nature through their consumption behavior and create a more intense consumer experience. With further developments (since the 1990s), additional considerations such as social welfare have also gained attention, although the environmental component has remained far more applied than social (Carrigan \& Attalla, 2001; Papaoikonomou, Ryan \& Valverde, 2011). Socially-related issues seemed to have a tougher time getting included in a product and being communicated through basic marketing tools like color, packaging and content. This discrepancy can, for example, still be seen in product labeling: environmental labels are much more clearly presented than are social labels (Dickson, 2001; UNOPS, 2009). Except for the fair trade label, social issues have not, in general, been widely popularized through product labeling; indeed, the question of how to promote purchasing with an emphasis on social issues still needs further consideration. Valor (2008) recognizes the need to develop a more complex and comprehensive label, one combining social and environmental issues that are more representative of a whole range of corporate social responsibility (CSR) complexities. Recent introduction of the concept of stakeholder orientation in marketing literature (Ferrell, Gonzalez-Padron, Hult \& Maignan, 2010) that emphasizes awareness and actions "on a variety of stakeholder issues" (p. 93) may show signs of placing more emphasis on social, rather than only natural, environmental issues in marketing. Developing social certification standards (SAI, 2008) and introduction of the "social fingerprint", in addition to the "environmental footprint" (Schmidt et al., 2004), could also be signs of progress in dealing with those issues more holistically.

\subsection{Sustainability dimensions as part of responsible consumer behavior - comparing literature and consumer perspective}

Socially conscious or responsible consumer behavior has been recognized as an important variable to study. Some of the earlier researchers have treated this behavior as a good segmentation base. Anderson \& Cunningham (1972) recognized the potential of "social consciousness" (e.g. giving your time to help society and do well at work) to be used in the consumer behavior context. In 1975, Webster Jr. clearly acknowledged the importance and responsibility of consumers for general well-being when he defined the socially conscious consumer as "a consumer who takes into account the public 
consequences of his or her private consumption or who attempts to use his or her purchasing power to bring about social change" (p. 188). He based this definition and research on the "social involvement" model. The model, however, did not prove to be appropriate for explaining socially responsible behavior; Webster himself admitted that his scale was biased toward more environmental issues. Early conceptualizations and operationalizations of responsible consumer behavior heavily favored the environmental dimension (Antil, 1984; Kinnear, Taylor \& Ahmed, 1974; Webster, 1975). "Green" consumerism, as one of the first specified responsible behaviors, was quite commonly seen as a part of socially responsible consumption (Roberts, 1995), even though the emphasis was always on environmental rather than social issues. The emphasis on specific issues (environmental, social) in naming and conceptualizing responsible consumer behavior created a mixture of poorly defined behaviors without equal representation of issues; therefore, a rather narrow view of consumer responsibility was developed.

Later authors did, however, start to make a distinction between socially and environmentally conscious consumption (Mayer, 1976) but were using them interchangeably or merging them under one construct (e.g. Belch, 1982). Roberts (1995) was one of the first to make a clearer distinction between environmental and social concerns and proposed a two-dimensional scale (social and environmental) for measuring responsible consumer behavior. Building on his work, Webb et al. (2008) also clearly distinguished between the dimensions of responsible behavior and concluded, after a literature review, that among the existing measures "none is an up-to-date measure of consumer behaviors in response to a full range of social issues" (p. 2). They developed a new measure, called Socially Responsible Purchase and Disposal, based on a definition of socially responsible consumer as "a person basing his or her acquisition, usage, and disposition of products on a desire to minimize or eliminate any harmful effects and maximize the long-run beneficial impact on society" (Mohr, Webb \& Harris, 2001, p. 47). With further developments, ethical responsibility has arisen as a social and corporate responsibility issue. "Green" consumption was usually seen as a predecessor or one of its parts (Freestone \& McGoldrick, 2008), combined with issues like animal welfare, which could not be placed under the "green" banner, and other issues connected with morality, as well as the general norms and values of society. This is reflected in a definition of ethical consumers as those "influenced by environmental, social justice, human health, and animal welfare issues in choosing products and services encompassing, alongside fair trade goods, 'sweat-free' clothes, 'cruelty-free' cosmetics, energy efficient appliances, and organic foods" (Low \& Davenport, 2005). Research on ethical consumption also presented some different and new antecedents compared to environmentally or socially responsible consumption. Seeing those issues all becoming a part of ethics has created an illusion that environmental and social issues are equally represented.

It is not surprising that our qualitative study also found that interviewed consumers placed a greater emphasis on environmental issues, which could be attributed to greater information availability and more perceived control connected with the natural environment. Participants were able to easily describe environmentally conscious consumers, while they were less likely to recall their own socially conscious purchases. Interviewees believed they know more about the exploitation of nature, while stories of social misconduct were less prevalent. Social injustice seems to be out of their control and has to be resolved by others, e.g. "countries where workers' rights are violated should be responsible for creating a safe work environment" (male, 33). Although the majority of interviewees did mention that caring for the natural and social environment is important and should be included in responsible behavior, they also usually saw themselves as being more concerned about either environmental or social issues. It seems that perception of the 
greater power/vulnerability of nature or man can be an indicator of whether people are more concerned about the natural or social environment, and their intentions for buying more environmentally or socially responsible products. This was also evident when comparing fair trade with environmental behaviors such as buying eco, bio or recyclable products. Fair trade is mostly unknown or only vaguely known and is, for the most part, not frequently purchased. One respondent offered a comparison with recyclable products: "materials exist that can be recycled and you cannot lie about that, with fair trade there is still a long chain and everybody can take something so the final link (worker) still does not get a fair share" (male, 33). Also, fair trade products are not seen on the shelves; thus, purchasing is limited. Unlike bio, eco products that seem to be connected with regular purchases (e.g. food), fair trade products seem to be more appropriate for special occasions (e.g. chocolate for gifts).

Consumers also had problems simultaneously expressing their concern for nature and society. They saw a potential conflict between being able to care simultaneously for nature and society "because for the good of nature you should buy less and for society more, so that more money goes around" (female, 63) or "I would rather buy on a farm, but I also need to drive there and exhaust gases, which is again not good" (female, 40). An observation of a female (32), who used to buy yoghurt from a home producer (seen as socially friendly), now buys ecologically produced yoghurt from a foreign producer (environmentally friendly) because of its eco certificate, also shows that consumers often need to make trade-offs between different sustainable behaviors. Based on personal interviews and a literature review, we suggest the following research propositions for further research:

$\boldsymbol{R P}$ 1: Consumers emphasize environmental dimensions of sustainability more than social dimensions in responsible consumer behavior.

$\boldsymbol{R P} 2$ : The more environmentally friendly consumer behavior is, the more socially friendly is their behavior too.
$\boldsymbol{R P}$ 3: The more trade-offs between environmental and social concerns a consumer perceives, the less he/she is willing to behave in a sustainable way.

\section{3. "Not only ethical" - expanded view of consumer responsibility from consumers' perspective}

Consumer responsibility seems to be a more conflicted concept than the more researched concept of corporate social responsibility. These two streams of research have emerged with different expectations of consumer actions: some believe it is a consumers' duty to act, as reflected in the consumer citizenship movement where consumers need to translate their rights into duties. According to them, it is the consumers' duty to be informed about environmental and social problems, to use this information for better (more sustainable, conscious) consumption decisions, and actively change their consumption when it has a negative impact on sustainability (Schrader, 2007). Others argue that we put too much pressure on consumers and that they sometimes do not have the ability to act, since there are too many obstacles to overcome which are out of the consumers' control (Moisander, 2007; Valor, 2008). Responsibility of consumers was usually seen and researched from the perspective of being motivated primarily by ethical or philanthropic concerns, although researchers also acknowledge that the responsibility which comes from self-interested or legal obligations can have positive environmental or social consequences (Belz \& Peattie, 2012).

Applying Carroll's (1991) proposition of corporate responsibility to the consumer context, the basis for all responsible consumer behaviors are economic behaviors. The economic responsibility of consumers could be seen as consumers' responsibility toward themselves, usually based on self-interest, needs, wishes, and general value-seeking consumer purchase behavior. Behaviors do not always need to be ethically motivated to have a positive influence on environment or society (Belz \& Peattie, 2012). 
Theories underlying self-interested, economic behavior include general exchange theory, social exchange theory and means-end theory (Bagozzi, 1975; Zeithaml, 1988), where the perceived gains/value of the behavior drives consumer actions. The following proposition is developed:

RP 4: Consumer behavior reflects to a higher degree their economic responsibility, compared to legal, ethical or philanthropic dimensions of consumer responsibility.

It is evident from the definition of marketing (American Marketing Association, December 17, 2007) that, from a marketing perspective, consumers are one of the most important stakeholder groups; value created in the process of strategy formulation and implementation is a core concept of marketing discipline (Gallarza, Gil-Saura \& Holbrook, 2011). In their review of sustainability research between 1998 and 2013, McDonagh and Prothero (2014) encourage a discussion on how marketers should "deliver sustainability as value" and conclude that "there is no reason why our raison d'être cannot become one of creating customer value with sustainability as its focal point" (p. 1206). In particular, mainstream consumers are often more goal and self-oriented and are not driven purely by concern for environment or society. They want to gain functional, emotional, and social value through their purchase behavior (Green \& Peloza, 2011; Sheth, Newman \& Gross, 1991) in exchange for their money (Bagozzi, 1975). Some authors have already observed some potential benefits/values commonly associated with green products (e.g. cost effectiveness, health and safety, status, and convenience) (Ottman, Stafford \& Hartman, 2006), but there is still a need for more precise taxonomy and examination of sources of perceived consumer benefits/values (Bhattacharya, Korschun \& Sen, 2009). We propose that economic responsibility be measured in the consumer context by the "perceived value" of environmentally and socially responsible products. Although it has been noted that "by creating social and envi- ronmental value, sustainability marketing tries to deliver and increase customer value" (Belz \& Schmidt-Riediger, 2010, p. 402), the concept of perceived value has rarely been used and measured in the context of responsible consumer behavior. So we put forward the following research proposition:

RP 5: Perceived value (emotional, social, and functional) for consumers is expected to be higher in environmentally responsible consumer behavior than in socially responsible consumer behavior.

In terms of trade-offs, one of the interviewees stated: "I always buy for my self-interest, but I can buy something that is less harmful for environment and society" (male, 33), while also adding: "you have to be healthy, this is good for society, otherwise you are a burden to society which has to pay for you. You have to be healthy first and in a good condition to help others." However, according to the interviewees, behavior still needs to be based on moderation and drawn from needs. From the concept of "mindful consumption", these behaviors can only be possible in circumstances where consumer needs are neither under- nor over-fulfilled but are, rather, "optimally fulfilled" (Sheth, Sethia \& Srinivas, 2011, p. 31). Buying from a farmers' market, for example, was often perceived in interviews as having a positive social impact; but the main reason for buying there is for one's own health, since products are perceived to be fresher and safer. Recent studies have concluded that, besides concern and altruism, general purchase criteria, such as status seeking, quality, and health, are important and can influence responsible consumption, thus supporting the following proposition (Griskevicius, Tybur \& Van den Bergh, 2010; Ottman, 2011).

$\boldsymbol{R P}$ 6: The more trade-offs between self- and other-regarding concerns consumers perceive, the less they are willing to act in a responsible way.

Ethical responsibility is connected to the morality, norms, and values that are reflected in consumer purchases and could also lead to a reduction in consumption or boycotting of products or 
companies. Smaller amounts of self-interest could also be important here, although in caring for others, nature and society is a priority. Theories underlying this process include models of moral development (Rest \& Barnett, 1986), marketing ethics (Hunt \& Vitell, 2006) and planned behavior (Ajzen, 1991). Here, behavior is driven by beliefs, as well as moral, ethical, normative, and attitudinal considerations. As a more direct predictor of behavior and "environmentally friendly product choices", "personal moral obligation" was found to be an important construct (Minton \& Rose, 1997). Similarly, Shaw, Shiu and Clarke (2000) found in their research of ethical consumers that "the measures of ethical obligation and self-identity are more pertinent to the TPB (theory of planned behavior) model than the traditional attitude and subjective norm measures" (p. 889). Thus, we propose measuring other-interested behaviors with the concept of ethical obligation. Ethical obligation can add a more holistic and balanced view of different motivations for responsible behavior, especially to explain socially responsible consumer behavior, which we expect brings less (economic/self-interested) value to consumers (Singhapakdi, Vitell, Rallapalli \& Kraft, 1996). We propose that ethical responsibility be measured with the "ethical obligation" construct in the consumer context.

$\boldsymbol{R P} 7:$ Ethical obligation is expected to be higher in socially responsible consumer behavior than in environmentally responsible consumer behavior.

Consumers' legal responsibilities can be described as obeying rules and laws connected to sustainability, such as buying energy-efficient light bulbs as prescribed by law. According to the interviewees, one of the responsibilities of consumers with social (economic) influence is also using products according to producers' instructions. Philanthropic responsibility could be seen as consumers' responsibility that is based on purely philanthropic acts, like giving donations for sustainable causes, which were more often mentioned in the interviews with regard to a potential social impact.

\section{FRAMEWORK OF CONSUMER RESPONSIBILITY AND SUSTAINABILITY IN THE CONSUMER CONTEXT}

To integrate the concepts of sustainability and responsibility in the consumer context, while also distinguishing between them, we propose the following framework based on the work of Chabowski et al. (2011); it is visually presented in Table 1 (Appendix):

o Sustainability: In a consumer context, sustainability could be seen as the dimension on which the emphasis of responsible (environmental, social, or economic) consumer behavior lies. It is a manifestation of consumers' interests and concerns, and presents a behavioral component of consumption. There exists a general, almost intuitive understanding that dimensions of sustainability (environmental, social) are different and that consumers who emphasize environmental or social/economic issues are not the same persons (Belz \& Peattie, 2012), although these differences between consumers are rarely conceptualized and researched (for an exception, see Roberts, 1995 and Webb et al., 2008).

o Responsibility: Consumer responsibility explains the consumer's intent; i.e. why he/she acts in a responsible way, and is a manifestation of motivations, as well as cognitive, emotional, or social consumption processes. To determine the components of consumer responsibility, we need to determine the purpose for that behavior. Consumer responsibility comprises many different reasons and motivations for behavior; it cannot be described solely as a behavior that has positive social or environmental influence. Drawing from the CSR field and interviews with consumers, we propose that - like corporate responsibility - consumer responsibility could also include several components that are most comprehensive- 
ly presented in the framework proposed by Carroll (1991). Her four-level pyramid structure of CSR actions (economic, legal, ethical, and philanthropic) implies that economic dimension is the basis on which all others are positioned.

\section{CONCLUSIONS AND IMPLICATIONS}

In this paper, we put forward several propositions regarding how to make research of responsible, sustainable consumer behavior more holistic; namely, by broadening the scope of researched issues (from environmental to social) and acknowledging that not all consumers act based on their ethical considerations but also on their self-interest. We made a clear distinction between responsibility and sustainability of consumer behavior, presented their different dimensions, and explored a variety of responsible consumption practices. Additionally, we presented this distinction in the framework of responsible, sustainable consumer behavior in order to better explain the complex and sometimes paradoxical behavior of responsible consumers. We explored consumer behaviors and dilemmas regarding all dimensions of responsible and sustainable behavior. We also proposed measures of perceived value and ethical obligation to measure self- and other-centered moti- vations for acting responsibly to make research more actionable. Such other- versus self-interested behaviors could potentially better explain the often mentioned gap between environmentally and socially responsible attitude and behavior, which may also be a gap between the interests of society and individual consumers. By understanding consumers' different emphasis of actions (environmental, social) and responsibility intentions (self-interest, other-interest), we can better understand and resolve consumer responsibility dilemmas that arise from a one-dimensional view. Only by acknowledging these different layers of sustainable and responsible consumption can we move sustainability research forward and change consumer behavior.

Marketers who employ environmentally and socially responsible marketing strategies need to understand not only why and how consumers react to their sustainability initiatives, how their activities influence consumer behavior, but also what value they bring to the consumer in order to ensure their satisfaction and loyalty and thus achieve their own marketing strategy objectives. Marketers need to understand consumers' intrinsic drive for action and how they should emphasize this in their behavior in order to align their strategic objectives with consumer needs and behavior so as to more efficiently target potential responsible consumers.

\section{References}

1. Ajzen, I. (1991). The theory of planned behavior. Organizational Behavior and Human Decision Processes, 50(2), 179-211.

2. Anderson Jr., W. T., \& Cunningham, W. H. (1972). The socially conscious consumer. Journal of Marketing, 36, 23-31.

3. Antil, J. H. (1984). Socially Responsible Consumers: Profile and Implications for Public Policy. Journal of Macromarketing, 4(2), 18-39.

4. Bagozzi, R. P. (1975). Marketing as Exchange. Journal of Marketing, 39(4), 32-39.

5. Barnett, C., Cafaro, P., \& Newholm, T. (2005). Philosophy and ethical consumption. In: R. Harrison, T. Newholm \& D. Shaw (Eds.), The Ethical Consumer (pp. 11-24). London: Sage.

6. Belch, M. A. (1982). A segmentation strategy for the 1980's: Profiling the socially-concerned market through life-style analysis. Journal of the Academy of Marketing Science, 10(4), 345-358.

7. Belz, F. M., \& Peattie, K. (2012). Sustainability marketing: a global perspective. London: John Wiley \& Sons. 
8. Belz, F. M., \& Schmidt-Riediger, B. (2010). Marketing strategies in the age of sustainable development: evidence from the food industry. Business Strategy and the Environment, 19(7), 401-416.

9. Bhattacharya, C. B., Korschun, D., \& Sen, S. (2009). Strengthening stakeholder-company relationships through mutually beneficial corporate social responsibility initiatives. Journal of Business Ethics, 85, 257-272.

10. Bridges, C. M., \& Wilhelm, W. B. (2008). Going Beyond Green: The "Why and How" of Integrating Sustainability Into the Marketing Curriculum. Journal of Marketing Education, 30(1), 33-46.

11. Carrigan, M., \& Attalla, A. (2001). The myth of the ethical consumer-do ethics matter in purchase behaviour?. Journal of Consumer Marketing, 18(7), 560-578.

12. Carrington, M. J., Neville, B. A., \& Whitwell, G. J. (2010). Why Ethical Consumers Don't Walk Their Talk: Towards a Framework for Understanding the Gap Between the Ethical Purchase Intentions and Actual Buying Behaviour of Ethically Minded Consumers. Journal of Business Ethics, 97(1), 139-158.

13. Carroll, A. B. (1991). The pyramid of corporate social responsibility: toward the moral management of organizational stakeholders. Business horizons, 34(4), 39-48.

14. Cato, M. S. (2009). Green economics: an introduction to theory, policy and practice. London: Earthscan/James \& James.

15. Chabowski, B. R., Mena, J. A., \& Gonzalez-Padron, T. L. (2011). The structure of sustainability research in marketing, 1958-2008: a basis for future research opportunities. Journal of the Academy of Marketing Science, 39(1), 55-70.

16. Choi, S., \& Ng, A. (2011). Environmental and Economic Dimensions of Sustainability and Price Effects on Consumer Responses. Journal of Business Ethics, 104(2), 269-282.

17. Creyer, E. H. (1997). The influence of firm behavior on purchase intention: do consumers really care about business ethics?. Journal of Consumer Marketing, 14(6), 421-432.

18. Dickson, M. A. (2001). Utility of no sweat labels for apparel consumers: profiling label users and predicting their purchases. Journal of Consumer Affairs, 35(1), 96-119.

19. Epstein, M. J. (2008). Making sustainability work: Best practices in managing and measuring corporate social, environmental, and economic impacts. San Francisco, CA: Berrett-Koehler Publishers.

20. Ferrell, O. C., Gonzalez-Padron, T. L., Hult, G. T. M., \& Maignan, I. (2010). From Market Orientation to Stakeholder Orientation. Journal of Public Policy \& Marketing, 29(1), 93-96.

21. Freestone, O. M., \& McGoldrick, P. J. (2008). Motivations of the ethical consumer. Journal of Business Ethics, 79(4), 445-467.

22. Gallarza, M. G., Gil-Saura, I., \& Holbrook, M. B. (2011). The value of value: Further excursions on the meaning and role of customer value. Journal of Consumer Behaviour, 10(4), 179-191.

23. Grebitus, C., Hartmann, M., Piorkowsky, M. B., Pakula, C., \& Stamminger, R. (2012). Editorial: Consumer behaviour towards a sustainable future. International Journal of Consumer Studies, 36(2), 121-122.

24. Green, T., \& Peloza, J. (2011). How does corporate social responsibility create value for consumers?. Journal of Consumer Marketing, 28(1), 48-56.

25. Griskevicius, V., Tybur, J. M., \& Van den Bergh, B. (2010). Going Green to Be Seen: Status, Reputation, and Conspicuous Conservation. Journal of Personality and Social Psychology, 98(3), 392-404.

26. Harrison, R., Newholm, T., \& Shaw, D. (2005). The ethical consumer. London: Sage Publications Ltd.

27. Hubbard, G. (2009). Measuring organizational performance: beyond the triple bottom line. Business Strategy and the Environment, 18(3), 177-191.

28. Hult, G. T. M. (2011). Market-focused sustainability: market orientation plus!. Journal of the Academy of Marketing Science, 39(1), 1-6.

29. Hunt, S. D., \& Vitell, S. J. (2006). The General Theory of Marketing Ethics: A Revision and Three Questions. Journal of Macromarketing, 26(2), 143-153. 
30. Jägel, T., Keeling, K., Reppel, A., \& Gruber, T. (2012). Individual values and motivational complexities in ethical clothing consumption: A means-end approach. Journal of Marketing Management, 28(3/4), 373-396.

31. Kinnear, T. C., Taylor, J. R., \& Ahmed, S. A. (1974). Ecologically Concerned Consumers: Who Are They?. Journal of Marketing, 38(2), 20-24.

32. Klick, J., \& Wright, J. (2012). Grocery Bag Bans and Foodborne Illness. Available at: http://ssrn.com/ abstract=2196481.

33. Low, W., \& Davenport, E. (2005). Has the medium (roast) become the message?: The ethics of marketing fair trade in the mainstream. International Marketing Review, 22(5), 494-511.

34. Mayer, R. N. (1976). The socially conscious consumer-another look at the data. Journal of Consumer Research, 3, 113-115.

35. McCracken, G. (1988). The Long Interview. Newbury Park, CA: SAGE Publications.

36. McDonagh, P., \& Prothero, A. (2014). Sustainability marketing research: past, present and future. Journal of Marketing Management, 30(11/12), 1186-1219.

37. McEachern, M. G., \& Carrigan, M. (2012). Revisiting contemporary issues in green/ethical marketing: An introduction to the special issue. Journal of Marketing Management, 28(3/4), 189-194.

38. Miles, M. B., \& Huberman, M. (1994). Qualitative Data Analysis: An Expanded Source Book. London: Sage.

39. Minton, A. P., \& Rose, R. L. (1997). The effects of environmental concern on environmentally friendly consumer behavior: An exploratory study. Journal of Business Research, 40(1), 37-48.

40. Mohr, L. A., Webb, D. J., \& Harris, K. E. (2001). Do consumers expect companies to be socially responsible? The impact of corporate social responsibility on buying behavior. Journal of Consumer affairs, 35(1), 45-72.

41. Moisander, J. (2007). Motivational complexity of green consumerism. International Journal of Consumer Studies, 31(4), 404-409.

42. Ottman, J. A. (2011). Focus on consumer self-interest to win today's green customer. Guardian Sustainable Business. Retrieved from: http://www.guardian.co.uk/sustainable-business/blog/ green-marketing-consumer-behaviour-change

43. Ottman, J. A., Stafford, E. R., \& Hartman, C. L. (2006). Avoiding Green Marketing Myopia: Ways to Improve Consumer Appeal for Environmentally Preferable Products. Environment: Science and Policy for Sustainable Development 48(5), 22-36.

44. Papaoikonomou, E., Ryan, G., \& Valverde, M. (2011). Mapping Ethical Consumer Behavior: Integrating the Empirical Research and Identifying Future Directions. Ethics \& Behavior, 21(3), 197-221.

45. Rest, J. R., \& Barnett, R. (1986). Moral development: Advances in research and theory. New York, NY: Praeger.

46. Roberts, J. A. (1995). Profiling levels of socially responsible consumer behavior: a cluster analytic approach and its implications for marketing. Journal of marketing Theory and practice, 3, 97-117.

47. SAI (2008). Social Accountability 8000. Retrieved from: http://www.sa-intl.org/_data/n_0001/resources/live/2008StdEnglishFinal.pdf

48. Schmidt, I., Meurer, M., Saling, P., Kicherer, A., Reuter, W., \& Gensch, C. O. (2004). Managing sustainability of products and processes with the socio-eco-efficiency analysis by BASF. Greener Management International, 45, 79-94.

49. Schrader, U. (2007). The moral responsibility of consumers as citizens. International Journal of Innovation and Sustainable Development, 2(1), 79-96.

50. Schrader, U., \& Thøgersen, J. (2011). Putting sustainable consumption into practice. Journal of Consumer Policy, 34(1), 3-8.

51. Seuring, S., \& Müller, M. (2008). From a literature review to a conceptual framework for sustainable supply chain management. Journal of cleaner production, 16(15), 1699-1710. 
52. Shaw, D., Shiu, E., \& Clarke, I. (2000). The contribution of ethical obligation and self-identity to the theory of planned behaviour: an exploration of ethical consumers. Journal of Marketing Management, 16(8), 879-894.

53. Sheth, J. N., Newman, B. I., \& Gross, B. L. (1991). Why we buy what we buy: a theory of consumption values. Journal of Business Research, 22(2), 159-170.

54. Sheth, J. N., Sethia, N. K., \& Srinivas, S. (2011). Mindful consumption: a customer-centric approach to sustainability. Journal of the Academy of Marketing Science, 39(1), 21-39.

55. Singh, J., de los Salmones Sanchez, M. M. G., \& del Bosque, I. R. (2008). Understanding corporate social responsibility and product perceptions in consumer markets: a cross-cultural evaluation. Journal of Business Ethics, 80(3), 597-611.

56. Singhapakdi, A., Vitell, S. J., Rallapalli, K. C., \& Kraft, K. L. (1996). The perceived role of ethics and social responsibility: A scale development. Journal of Business Ethics, 15(11), 1131-1140.

57. UNOPS (2009). A guide to environmental labels for Procurement Practitioners of the United Nations System. Retrieved from: https://www.ungm.org/Areas/Public/Downloads/Env_Labels_Guide. pdf

58. Valor, C. (2008). Can consumers buy responsibly? Analysis and solutions for market failures. Journal of Consumer Policy, 31(3), 315-326.

59. Webb, D. J., Mohr, L. A., \& Harris, K. E. (2008). A re-examination of socially responsible consumption and its measurement. Journal of Business Research, 61(2), 91-98.

60. Webster Jr., F. E. (1975). Determining the characteristics of the socially conscious consumer. Journal of Consumer Research, 2, 188-196.

61. Zeithaml, V. A. (1988). Consumer perceptions of price, quality, and value: a means-end model and synthesis of evidence. Journal of Marketing, 52, 2-22. 


\section{Appendix}

TABLE 1: Framework for researching responsibility and sustainability in consumer contexts and examples of environmentally and socially oriented (responsible) consumer behaviors

\begin{tabular}{|c|c|c|c|c|c|}
\hline \multirow{2}{*}{\multicolumn{2}{|c|}{$\begin{array}{l}\text { RESPONSIBILITY } \\
\text { (INTENT) } \Rightarrow \\
\text { SUSTAINABILITY } \\
\text { (EMPHASIS) }\end{array}$}} & \multicolumn{2}{|c|}{ SELF-INTEREST } & \multicolumn{2}{|c|}{ OTHER-INTEREST } \\
\hline & & Economic & Legal & Ethical & Philantropic \\
\hline \multirow{4}{*}{ 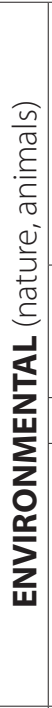 } & Purchase & $\begin{array}{l}\text { Organic, natural, bio } \\
\text { products (e.g. food), } \\
\text { using vinegar for } \\
\text { cleaning }(f, 40)) \text {. }\end{array}$ & $\begin{array}{l}\text { No plasticl } \\
\text { recycled and } \\
\text { paper bags } \\
\text { usage }(f, 49) ; \\
\text { Light bulbs. }\end{array}$ & $\begin{array}{c}\text { Animal welfare protection } \\
\text { products ("cruelty-free" } \\
\text { cosmetic testing); } \\
\text { Environmentally friendly } \\
\text { packaging like glass, refills, } \\
\text { smaller packaging; (f64). }\end{array}$ & $\begin{array}{l}\text { Gifts with } \\
\text { environmental } \\
\text { purpose. }\end{array}$ \\
\hline & $\begin{array}{l}\text { Usage/ } \\
\text { possession }\end{array}$ & \multirow{2}{*}{\multicolumn{2}{|c|}{$\begin{array}{l}\text { Using and disposing products by } \\
\text { producer's instructions (f, 30). }\end{array}$}} & $\begin{array}{l}\text { Driving less, driving a bikel } \\
\text { taking bus, energy efficient } \\
\text { products }(m, 53) \text {. }\end{array}$ & / \\
\hline & Disposal & & & Recycling, reusing $(f, 49)$. & / \\
\hline & $\begin{array}{l}\text { Other } \\
\text { (citizenship, } \\
\text { lifestyles) }\end{array}$ & $\begin{array}{c}\text { Permaculture and } \\
\text { eco villages. } \\
\text { Buying quality } \\
\text { products that last } \\
\text { longer and produce } \\
\text { less garbage }(m, 53) \text {. }\end{array}$ & / & Buying less (m, 53). & $\begin{array}{l}\text { Donations for } \\
\text { environmental } \\
\text { causes. }\end{array}$ \\
\hline \multirow{4}{*}{ 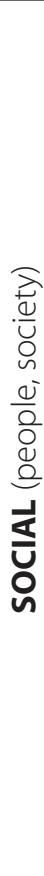 } & Purchase & $\begin{array}{c}\text { Products bought } \\
\text { on farmers market, } \\
\text { local or regional or } \\
\text { continental (Europe) } \\
\text { products (m, 31). } \\
\text { Not buying specific } \\
\text { categories (sweets, } \\
\text { chips, alcohol,...) } \\
(f, 40) .\end{array}$ & $\begin{array}{l}\text { Paying for } \\
\text { purchases (f, } \\
\text { 30). }\end{array}$ & $\begin{array}{l}\text { Fair trade (f, 28); Products } \\
\text { made without child labor, } \\
\text { "sweat-free" products } \\
\text { (clothes). }\end{array}$ & $\begin{array}{c}\text { Buying for } \\
\text { or from less } \\
\text { privileged } \\
(f, 40 ; \text { e.g. } \\
\text { magazines } \\
\text { from } \\
\text { homeless). }\end{array}$ \\
\hline & $\begin{array}{l}\text { Usage/ } \\
\text { possession }\end{array}$ & \multirow{2}{*}{\multicolumn{2}{|c|}{$\begin{array}{l}\text { Product (e.g. car) sharing, using } \\
\text { and disposing products by } \\
\text { producer's instructions (f, 30). }\end{array}$}} & / & / \\
\hline & Disposal & & & $\begin{array}{l}\text { Cleaning closets and } \\
\text { giving products forward } \\
\text { (e.g. clothes for charity; m, } \\
\text { 31), collecting bottle caps } \\
\text { for charitable purposes. }\end{array}$ & / \\
\hline & $\begin{array}{l}\text { Other } \\
\text { (citizenship, } \\
\text { lifestyles) }\end{array}$ & $\begin{array}{l}\text { Slow food } \\
\text { movement; } \\
\text { Cohousing } \\
\text { communities. }\end{array}$ & / & & $\begin{array}{l}\text { Donations for } \\
\text { social causes } \\
\text { (to charity). }\end{array}$ \\
\hline
\end{tabular}

